\title{
NATURE OF GENE ACTION FOR SOME ECONOMIC CHARACTERS OF TOMATO (Lycopersicon esculentum L.) VARIETIES
}

\author{
M. S. Hamada'; A. F. Hamaiel ${ }^{2}$; S. M. Faried ${ }^{3}$ and Sara A. A. \\ Elkomey $^{3}$ \\ 1- Dept. Genetics, Fac. Agric., Damietta Univ., Egypt. 2- Dept. \\ Vegetables and Floriculture, Fac. Agric., Damietta Univ., Egypt. 3- \\ Horticultural Research Inst., Agri. Res. Center, Egypt.
}

\begin{abstract}
Knowledge about the mode of gene action of economical traits (which directly contribute towards yield and fruit quality) in any crop like tomato (lycopersicon esculentum L.) helps to formulate the genetic basis for breeding. Thus, the aim of the present study was to estimate different types of gene action affecting some characteristics of tomato. For this purpose, five tomato varieties were used. These varieties were: Advantage $2\left(P_{1}\right)$, Cherry $\left(P_{2}\right)$, Fatma $\left(P_{3}\right)$, Edkaway $\left(P_{4}\right)$ and Castle Rock $\left(P_{5}\right)$. The varieties were crossed by using complete diallel crosses mating design, in order to produce 20 hybrids. All genotypes were evaluated during two seasons for some vegetative traits, fruit characteristics and physiological traits. The data were subjected to biometrical analysis and the obtained results revealed that the mean squares of entries were highly significant for the studied traits, leading to the further partitioning of genetic variance into its components. The combined data over the two seasons showed that additive genetic variances were higher than their corresponding values of dominance genetic variances for plant height and number of primary branches per plant. On the other hand, values of dominance genetic variances were higher than their corresponding values of additive genetic variances for leaf area, fruit characters and chemical traits. Furthermore, heritability in broad sense $\left(h^{2} b \%\right)$ was $93.15 \%$ for plant height, $85.32 \%$ for number of primary branches per plant, $78.68 \%$ for leaf area, $-92.38 \%$ for locules number per fruit, $97.02 \%$ for firmness fruit, $68.78 \%$ for Pericarp thickness, $71.62 \%$ for total soluble solids, $81.58 \%$ for ascorbic acid content and $87.13 \%$ for lycopene content. However, heritability estimates in narrow sense $\left(h^{2} n \%\right)$ were more less than the corresponding values in all studied traits, indicating that the role of non-additive genetic variance in the genetic expression of these traits are non-negligible. These genetic parameters could be used in carrying out breeding programs suitable for Tomato.
\end{abstract}

\section{INTRODUCTION}

Tomato (Solanum lycopersicum), early was known as (lycopersicon esculentum L.) is one of the most important vegetables in the world including Egypt. Tomato is a rich source of antioxidants (mainly lycopene and $\beta$-carotene), vitamin $A$, vitamin $C$ and minerals 
like $\mathrm{Ca}, \mathrm{P}$ and Fe. Vegetative traits such as plant height (P.H), number of primary branches per plant (N.P.B) and leaf area (L.A), fruit characteristics such as locules numbser per fruit (N.L.F), firmness fruit (F.F) and Pericarp thickness (P.T) and physiological traits such as total soluble solids (T.S.S), ascorbic acid content (V.C) and lycopene content (Lyco.) are the most important traits in a breeding program. Understanding the nature of gene action with respect to the relative magnitudes of additive and non-additive genetic variances requires the determination of the different variance components due to general combining ability (GCA) and specific combining ability (SCA). Dod et al. (1992) found that higher magnitude of GCA compared with SCA for locules number per fruit and Pericarp thickness indicating a predominant role for additive gene action. Ashrafuzzaman et al., (2010) and Singh et al., (2011) found that GCA values were large in magnitudes than the corresponding values of SCA for plant height, number of primary branches per plant and leaf area. On the other hand, Kumar et al., (2013) found highly significant variation due to GCA as well as SCA indicating the importance of the additive as well as the non-additive variation for total soluble solids, ascorbic acid content and lycopene content governed by non-additive.

Therefore, these estimates were of great values in establishing the most promising approach. Thus, the present investigation aimed to obtain estimates for the different types of gene action in terms of general combining ability and specific combining ability by evaluating the diallel crosses mating design. Heterosis and maternal effect were also investigated in this study.

\section{MATERIAL AND METHODS}

In this investigation five tomato varieties belong to species (Lycopersicon esculentum Mill) were used. These varieties were Advantage $2\left(P_{1}\right)$, Cherry $\left(P_{2}\right)$, Fatma $\left(P_{3}\right)$, Edkaway $\left(P_{4}\right)$ and Castle Rock $\left(P_{5}\right)$. The seeds of these varieties were obtained from the National Gene Bank at the Agriculture Reseearch Center, Giza. Individual plants from each variety were self pollinated for three generations to end up with an inbred line from each variety. This work was carried out during three successive generations at a private farm in Industrial Gamasa region, Dakahlia under the supervision of the Department of Genetics, Faculity of Agriculture, Damietta University.

Self seeds from each variety were planted during the summer season of 2013 at a private farm as mentioned above. At the flowering time, all single crosses including reciprocals were made among these varities according to complete diallel design to produce $10 F_{1}$ hybrids and $10 \mathrm{~F}_{1 \mathrm{r}}$ reciprocal hybrids. Furthermore, all genotypes were evaluated during the summer season of 2014 and winter season 2015 
at a private farm in Industrial Gamasa region, Dakahlia. The genotypes were sown in nursery in seedling trays on first of February 2014 as the summer season and the first of November 2014 as the winter season. The experimental design used was the randomized complete block design with three replications.

Data were recorded on ten guarded and labled randomly chosen plants per plot for all entries in the two growing seasons. Plant height, Number of primary branches per plant, Leaf area, Locules number per fruit, Firmness fruit, Pericarp thickness, Total soluble solids, Ascorbic acid content and Lycopene content were the measured characters.

The obtained data for these traits from each season and the combined data over the two seasons were subjected to biometerical analysis using the procedures described by Griffing Method III (1956) and outlined by Singh and Chaudhary (1985).

The covariance of relative was translated into appropriate genetic components of variance as outlined by Matzinger and Kompthorne (1956) and Cocherham (1963) as follows:

$$
\begin{aligned}
& \left(\sigma^{2} g\right)=1 / 2\left(\sigma^{2} A\right) \quad \text { or } \quad\left(\sigma^{2} A\right)=2 \sigma^{2} g \\
& \sigma^{2} D=\sigma^{2} s
\end{aligned}
$$

where: $\sigma^{2} s$ is the variance of specific combining ability.

In addition, the dominance degree ratio as well as the heritabilities were determined using the following equations:

\section{Dominance degree ratio (Dd):}

$\mathrm{Dd}=\sqrt{\frac{\sigma^{2} D}{\sigma^{2} A}}$

The heritability values were estimated as follows:

1. From single season:

Broad sense heritability:

$\mathrm{H}^{2}=\frac{\sigma^{2} A+\sigma^{2} D}{\sigma^{2} A+\sigma^{2} D+\sigma^{2} r+\sigma^{2} e / k} \times 100$

Narrow sense heritability:

$\mathrm{h}_{\mathrm{n}}^{2}=\frac{\sigma^{2} A}{\sigma^{2} A+\sigma^{2} D+\sigma^{2} r+\sigma^{2} e / k} \times 100$

\section{From combined data over seasons:}

Broad sense heritability:

$$
\mathrm{h}^{2}{ }_{\mathrm{b}}=\frac{\sigma A^{2}+\sigma^{2} D}{\sigma^{2} A+\sigma^{2} D+\sigma^{2} r+Y+\sigma^{2} D Y / Y+\sigma^{2} r Y / Y+\sigma^{2} e / k Y} \times 100
$$

Narrow sense heritability: 
$\mathrm{h}_{\mathrm{n}}^{2}=\frac{\sigma^{2} A}{\sigma^{2} A+\sigma^{2} D+\sigma^{2} r+\sigma^{2} A Y / Y+\sigma^{2} D Y / Y+\sigma^{2} r Y / Y+\sigma^{2} e / k Y} \times 100$

\section{RESULTS AND DISCUSSION}

The results of the analysis of combining ability for vegetative traits under study with respect to each season and their combined data are shown in Table 1. The results revealed that the mean squares of GCA, SCA and reciprocal effects were significant for plant height at the first season and combined data and number of primary branches per plant at the second season and combined data which indicate the importance of both additive and non-additive genetic variances and the cytoplasmic factors which play a major role in the genetic expression of these traits. While, leaf area exhibited a highly positive significance for (SCA) variance and reciprocal effects, implying that non-additive genetic variance was important for this trait. Furthermore, these results were emphasized by the ratio of (GCA) to (SCA) variance which was higher than unity for plant height and number of primary branches per plant indicating the predominance of the additive gene action. On the other hand, the interaction of GCA, SCA and reciprocal with seasons were not significant for all vegetative traits, except for leaf area (L.A) in the case of GCA by season interaction. This finding suggested that these parameters are highly stable with different environmental conditions with respect to the studied vegetative traits. The present results are in agreement with those reported by Ashrafuzzaman et al. (2010) and Singh et al. (2011).

The results of analysis of combining ability for fruit characters are presented in Table 2. The results revealed that GCA, SCA and reciprocal were highly significant for fruit firmness (F.F), which indicated the importance of both additive and non-additive genetic variance and cytoplasmic factors which play a major role in the genetic expression of these traits. Locules number per fruit (N.L.F) and Pericarp thickness (P.T) exhibited highly positive significance for (SCA) variance, implying that non-additive genetic variance was important for both traits. These results were emphasized by the ratio of (GCA) to (SCA) variance which was higher than unity for firmness fruit indicating the predominance of the additive gene action. On the other hand, the interaction of GCA, SCA and reciprocal with seasons were not significant for locules number per fruit, for fruit firmness indicating that these parameters are stable with different environments. While, the interaction of GCA, SCA and reciprocal with seasons was significant for pericarp thickness. This finding referred to that these parameters were unstable with different environments. In this manner, 
many investigators obtained the same results, among them Sekhar et al. (2010).

The analysis of combining ability results for fruit characters are presented in Table 3. Tests of significance of the mean squares showed significance for (SCA) variance and reciprocal effect for total soluble solids (T.S.S), ascorbic acid content (V.C) and lycopene content (Lyco.) at the first and second seasons, implying that nonadditive genetic variance was important for these traits. On the other hand, the interaction of GCA, SCA and reciprocal with seasons was not significant for all chemical traits, except for ascorbic acid content (V.C). This finding indicates that these parameters are highly stable with different environmental conditions with respect to the studied chemical traits. Similar results were obtained by Seema et al. (2005) and Santosh and Sharma (2011).

The results of genetic parameters and heritability estimated for vegetative traits for both seasons and combined data are presented in Table 4. The results revealed that the magnitude of additive genetic variances $\left(\sigma^{2} A\right)$ were larger than their corresponding of non-additive genetic variance including dominance $\left(\sigma^{2} D\right)$ for plant height and number of primary branches per plant at the first and second seasons. While, in case of leaf area, the result showed that the magnitude of non-additive genetic variance was larger than their corresponding of additive genetic variance. This finding is emphasized by dominance degree ratio $(\mathrm{Dd})$, which was less than one for plant height and number of primary branches indicating the major role of additive genetic variance in the performance of these two traits and selection program for improvement of these traits is recommended. While, it was more than one in the case of leaf area, indicating the major role of dominance genetic variance in the inheritance of this trait and the hybridization for improving this trait is proper. Therefore, the heritability in broad sense $\left(h^{2} b \%\right)$ was high and close to heritability in narrow sense estimates for plant height and number of primary branches which were $91.63 \%, 89.74 \%$ and $93.15 \%$ for plant high and $91.41 \%$, $77.69 \%$ and $85.32 \%$ for number of primary branches with respect to first season, second season and combined data, respectively. However, heritability estimates in narrow sense $\left(h^{2} n \%\right)$ were $75.73 \%$, $84.89 \%$ and $67.2 \%$ for plant height and $46.73 \%, 49.85 \%$ and $26.94 \%$ for number of primary branches with respect to first season, second season and combined data, respectively. Furthermore, the results also showed that variance due to non-additive by seasons interactions ( $\sigma$ ${ }^{2} \mathrm{DS}$ ) were negative for plant height and number of primary branches. This finding indicated that these genetic parameters are stable with different environmental conditions. Similar results were obtained by Dodhol et al. (1999) and Salib (1999). 
Different genetic parameters and heritability were estimated for some tomato traits which including locules number per fruit (N.L.F), fruit firmness (F.F) and pericarp thickness (P.T) for both seasons and combined data, and the results are presented in Table 5 . The results revealed that the magnitudes of dominance genetic variance $\left(\sigma^{2} D\right)$ was larger than their corresponding of additive genetic variance $\left(\sigma^{2} A\right)$ for all studied traits for both seasons and combined data except firmness fruit (F.F). These results could be emphasized by dominance degree ratio (Dd), which showed more than one for these traits. Thus, the suitable breeding program for improvement of these traits is production of hybrids. Therefore, heritability in broad sense was larger in magnitudes than their corresponding estimates in narrow sense for all studied traits with respect to the combined data over the two seasons. Heritability estimates in broad sense $\left(h^{2} b \%\right)$ were $72.1 \%, 88.11 \%$ and $-92.39 \%$ for locules number per fruit, $94.42 \%, 93.62 \%$ and $97.02 \%$ for fruit firmness and $96.76 \%, 91.51 \%$ and $68.78 \%$ for pericarp thickness with respect to the first season, second season and combined data, respectively. However, heritability estimates in narrow sense $\left(h^{2} n \%\right)$ were $-73.62 \%$, -113.08 and -25.57 for locules number per fruit, $64.66 \%, 56.95 \%$ and $40.73 \%$ for fruit firmness and $17.65 \%, 14.97 \%$ and $10.39 \%$ for pericarp thickness with respect to first season, second season and combined data, respectively. Also, the results indicated that the interaction between genotypic parameters and seasons $\left(\sigma^{2} A x S\right)$, $\left(\sigma^{2} \mathrm{DxS}\right)$ and $\left(\sigma^{2} \mathrm{rxS}\right)$ were very low for the fruit characteristics. This finding indicated that these traits were less affected by environmental components with different degrees. Similar results were obtained by LiHui (2006), Hannan et al. (2007), and Koansouh and Zakher (2011).

Genetic parameters and heritability estimated for chemical traits including total soluble solids (T.S.S), ascorbic acid content (V.C) and lycopene content (Lyco.) for both seasons and combined data are presented in Table 6 . The results indicated that the estimates of the non-additive $\left(\sigma^{2} D\right)$ were larger than their corresponding of additive genetic variance $\left(\sigma^{2} A\right)$ for all studied traits. This was emphasized by dominance degree ratio which was more than one. In addition, the heritability in broad sense was large in magnitudes than their corresponding estimates in narrow sense. . Heritability estimates in broad sense $\left(\mathrm{h}^{2} \mathrm{~b} \%\right)$ were $88.78 \%, 85.01 \%$ and $71.62 \%$ for total soluble solids, $61.56 \%, 54.17 \%$ and 81.58 for ascorbic acid content and $83.87 \%, 85.28 \%$ and $87.13 \%$ for lycopene content with respect to the first season, second season and combined data, respectively. While, heritability estimates in narrow sense $\left(h^{2} n \%\right)$ were $42.59 \%$, $31.11 \%$ and $-10.94 \%$ for total soluble solids, $32.31 \%, 2500 \%$ and $1.31 \%$ for ascorbic acid content and $-3.23 \%,-1.23 \%$ and $20.46 \%$ for 
lycopene content with respect to first season, second season and combined data ,respectively. Thus, the suitable breeding program for the improvement of these traits is production of hybrids. Furthermore, the variances due to the interaction between additive gene action and reciprocal effect with seasons were negative in the case of T.S.S and the corresponding magnitudes of non-additive with seasons variance were positive in this trait. This finding indicated that the additive gene action is more stable with different environmental conditions. While, the magnitudes of additive, non-additive and reciprocal with season interaction variance were positive for lycopene content. This indicated that these genetic parameters are unstable with different environmental conditions. Similar results were obtained by Garg et al., (2008), Adalid et al., (2012) and El-Nagashy (2012).

\section{CONCLUSION}

In conclusion, due to the pervious results, which confirmed the role of both additive and non-additive genetic variances in the inheritance of studied traits with different levels, the suggested suitable breeding program for improving these traits is recurrent selection program for vegetative traits and production of hybrids for fruit characters and chemical traits.

Table 1: Analysis of combining ability and mean square estimates for some vegetative traits at each season and combined data over the two seasons

\begin{tabular}{|c|c|c|c|c|c|c|c|c|c|c|c|}
\hline \multirow{2}{*}{ S.V } & \multicolumn{2}{|c|}{ DF } & \multicolumn{3}{|c|}{ P.H } & \multicolumn{3}{|c|}{ N.P.B } & \multicolumn{3}{|c|}{ L.A } \\
\hline & single & comb & S1 & S2 & Comb & S1 & S2 & Comb & $\mathrm{S} 1$ & S2 & Comb \\
\hline Hybrids & 19 & 19 & $500.3^{\star *}$ & $537.9^{* *}$ & $1014.4^{\star *}$ & $9.48^{* *}$ & $8.11^{* *}$ & $16.19^{* *}$ & $25.24^{* *}$ & $27.94^{\star *}$ & $50.75^{\star}$ \\
\hline GCA & 4 & 4 & $589.5^{\star *}$ & $558.5^{\star \star}$ & $1122.8^{\star \star}$ & $18.26 \mathrm{~ns}$ & $11.26^{*}$ & $27.40^{\star \star}$ & $1.86 \mathrm{~ns}$ & $5.53 \mathrm{~ns}$ & $3.457 \mathrm{~ns}$ \\
\hline SCA & 5 & 5 & $88.56^{*}$ & $40.59^{* *}$ & $119.1^{* *}$ & $7.51^{* *}$ & $3.860^{*}$ & $10.52^{\star *}$ & $28.25^{\star \star}$ & $25.87^{\star \star}$ & $49.61^{\star *}$ \\
\hline $\mathrm{RE}$ & 10 & 10 & $670.5^{\star *}$ & $778.3^{\star \star}$ & $1418.6^{\star \star}$ & $6.96^{\star *}$ & $8.98^{* *}$ & $14.54^{* *}$ & $33.08^{* *}$ & $37.94^{* *}$ & $70.23^{\star \star}$ \\
\hline Hybrids $\times \mathrm{S}$ & & 19 & & & $23.87 n s$ & & & $1.412 \mathrm{~ns}$ & & & $2.427^{\star}$ \\
\hline $\mathrm{GCA} \times \mathrm{S}$ & & 4 & & & $25.29 n s$ & & & $2.120 \mathrm{~ns}$ & & & $3.946^{*}$ \\
\hline $\mathrm{SCA} \times \mathrm{S}$ & & 5 & & & $10.05 n s$ & & & $0.853 \mathrm{~ns}$ & & & $4.505^{\star \star}$ \\
\hline$R E \times S$ & & 10 & & & $30.20 \mathrm{~ns}$ & & & $1.408 \mathrm{~ns}$ & & & $0.780 \mathrm{~ns}$ \\
\hline Error & 38 & 76 & 18.46 & 20.87 & 19.67 & 0.659 & 1.104 & 0.882 & 1.224 & 1.203 & 1.214 \\
\hline
\end{tabular}

** and * significant at 1 and $5 \%$ probability levels respectively by $\mathrm{F}$ test and random effects of both genotypes and years.

Table 2: Analysis of combining ability and mean square estimates for fruit characters at each season and combined data over the two seasons

\begin{tabular}{|c|c|c|c|c|c|c|c|c|c|c|c|}
\hline \multirow{2}{*}{ S.V } & \multicolumn{2}{|c|}{ DF } & \multicolumn{3}{|c|}{ N.L.F } & \multicolumn{3}{|c|}{ F.F } & \multicolumn{3}{|c|}{ P.T } \\
\hline & Single & comb & S1 & S2 & comb & S1 & S2 & Comb & S1 & S2 & Comb \\
\hline Hybrids & 19 & 19 & $2.859^{* *}$ & $2.880^{\star \star}$ & $5.629^{\star \star}$ & $2.959^{* *}$ & $2.176^{\star *}$ & $5.036^{* *}$ & $4.389^{* *}$ & $1.862^{* \star}$ & $5.394^{\star *}$ \\
\hline GCA & 4 & 4 & $0.766^{\star *}$ & $0.656^{\star \star}$ & $1.389^{\star \star}$ & $4.227^{\star * *}$ & $2.474^{*}$ & $6.568^{\star \star}$ & $7.665 \mathrm{~ns}$ & $2.115 n s$ & $8.727 n s$ \\
\hline SCA & 5 & 5 & $2.484^{* *}$ & $3.622^{* *}$ & $5.864^{\star \star}$ & $1.062^{* *}$ & $0.787^{* *}$ & $1.835^{* *}$ & $5.772^{* *}$ & $1.655^{\star *}$ & $6.078^{* *}$ \\
\hline $\mathrm{RE}$ & 10 & 10 & $3.883^{\star \star}$ & $3.400^{\star \star}$ & $7.208^{\star \star}$ & $3.399^{* \star}$ & $2.752^{\star \star}$ & $6.025^{\star *}$ & $2.387^{\star \star}$ & $1.865^{\star \star}$ & $3.718^{\star \star}$ \\
\hline $\begin{array}{c}\text { Hybrids } x \\
S\end{array}$ & & 19 & & & $0.110 \mathrm{~ns}$ & & & $0.098 \mathrm{~ns}$ & & & $0.857^{\star \star}$ \\
\hline $\mathrm{GCA} \times \mathrm{S}$ & & 4 & & & $0.033 \mathrm{~ns}$ & & & $0.134 \mathrm{~ns}$ & & & $1.052^{\star \star}$ \\
\hline SCA $\times S$ & & 5 & & & $0.241 \mathrm{~ns}$ & & & $0.014 \mathrm{~ns}$ & & & $1.349^{\star \star}$ \\
\hline$R E \times S$ & & 10 & & & $0.075 \mathrm{~ns}$ & & & $0.126 \mathrm{~ns}$ & & & $0.533^{* \star}$ \\
\hline Error & 38 & 76 & 0.217 & 0.104 & 0.161 & 0.091 & 0.063 & 0.077 & 0.116 & 0.087 & 0.101 \\
\hline
\end{tabular}

** and ${ }^{*}$ significant at 1 and $5 \%$ probability levels respectively by $F$ test and random effects of both genotypes and years. 
Table 3: Analysis of combining ability and mean square estimates for the studied chemical traits at each season and combined data over the two seasons

\begin{tabular}{|c|c|c|c|c|c|c|c|c|c|c|c|}
\hline \multirow{2}{*}{ S.V } & \multicolumn{2}{|c|}{ DF } & \multicolumn{3}{|c|}{ T.S.S } & \multicolumn{3}{|c|}{ V.C } & \multicolumn{3}{|c|}{ Lyco. } \\
\hline & Single & comb & $\mathrm{S} 1$ & S2 & Comb & $\mathrm{S} 1$ & S2 & Comb & $\mathrm{S} 1$ & S2 & Comb \\
\hline Hybrids & 19 & 19 & $304.2^{* *}$ & $173.1^{\star *}$ & $1.158^{\star *}$ & $0.156^{\star *}$ & $0.119^{\star \star}$ & $0.013^{* *}$ & $0.049^{\star *}$ & $0.042^{\star *}$ & $454.4^{\star \star}$ \\
\hline GCA & 4 & 4 & $435.4 \mathrm{~ns}$ & $176.2 \mathrm{~ns}$ & $0.872^{\star \star}$ & $0.116 \mathrm{~ns}$ & $0.043 \mathrm{~ns}$ & $0.019^{* *}$ & $0.056 \mathrm{~ns}$ & $0.050 \mathrm{~ns}$ & $572.9^{\star *}$ \\
\hline SCA & 5 & 5 & $196.0^{* *}$ & $100.1^{\star *}$ & $1.828^{\star *}$ & $0.058^{* *}$ & $0.025^{\star *}$ & $0.020^{* *}$ & $0.059^{* *}$ & $0.051^{\star *}$ & $276.8^{\star \star}$ \\
\hline $\mathrm{RE}$ & 10 & 10 & $305.9^{* *}$ & $208.3^{\star *}$ & $0.938^{\star *}$ & $0.221^{\star *}$ & $0.195^{\star \star}$ & $0.007^{* *}$ & $0.041^{\star *}$ & $0.035^{\star *}$ & $495.8^{\star \star}$ \\
\hline $\begin{array}{c}\text { Hybrids } x \\
\text { S }\end{array}$ & & 19 & & & $0.129 \mathrm{~ns}$ & & & $0.002^{* *}$ & & & $22.87 \mathrm{~ns}$ \\
\hline $\mathrm{GCA} \times \mathrm{S}$ & & 4 & & & $0.070 \mathrm{~ns}$ & & & $0.002^{* *}$ & & & $38.80 \mathrm{~ns}$ \\
\hline SCA $\times S$ & & 5 & & & $0.332^{\star \star}$ & & & $0.002^{*}$ & & & $19.29 \mathrm{~ns}$ \\
\hline $\mathrm{RE} \times \mathrm{S}$ & & 10 & & & $0.050 \mathrm{~ns}$ & & & $0.001^{*}$ & & & $18.29 \mathrm{~ns}$ \\
\hline Error & 38 & 76 & 19.14 & 12.22 & 0.082 & 0.023 & 0.011 & 0.001 & 0.005 & 0.004 & 15.68 \\
\hline
\end{tabular}

** and * significant at 1 and $5 \%$ probability levels respectively by $F$ test and random effects of both genotypes and years.

Table 4: Estimates of genetic parameters and heritability in broad and narrow senses for the studied vegetative traits

\begin{tabular}{|c|c|c|c|c|c|c|c|c|c|}
\hline \multirow[t]{2}{*}{ GP } & \multicolumn{3}{|c|}{ P.H } & \multicolumn{3}{|c|}{ N.P.B } & \multicolumn{3}{|c|}{ L.A } \\
\hline & S1 & S2 & comb & S1 & S2 & comb & S1 & S2 & Comb \\
\hline$\sigma^{2} A$ & 167 & 172.6 & 141.2 & 3.583 & 2.467 & 2.23 & -8.795 & -6.77 & -6.513 \\
\hline$\sigma^{2} D$ & 35.05 & 9.86 & 54.53 & 3.426 & 1.378 & 4.834 & 13.513 & 12.334 & 22.55 \\
\hline$\sigma^{2} r$ & 326 & 378.7 & 694.2 & 3.154 & 3.941 & 6.566 & 15.928 & 18.369 & 34.73 \\
\hline$\sigma^{2} A \times S$ & & & 4.354 & & & 0.362 & & & -0.162 \\
\hline$\sigma^{2} D \times S$ & & & -9.62 & & & -0.029 & & & 3.291 \\
\hline$\sigma^{2} r \times S$ & & & 10.53 & & & 0.526 & & & -0.434 \\
\hline $\mathbf{h}^{2} \mathbf{b} \%$ & 91.63 & 89.74 & 93.15 & 91.41 & 77.69 & 85.32 & 79.4 & 82.2 & 78.68 \\
\hline$h^{2} n \%$ & 75.73 & 84.89 & 67.2 & 46.73 & 49.85 & 26.94 & -148 & -100.27 & -31.95 \\
\hline D.d & 0.458 & 0.239 & 0.621 & 0.978 & 0.747 & 1.472 & -1.239 & -1.349 & -3.179 \\
\hline
\end{tabular}

Table 5: Estimates of genetic parameters and heritability in broad and narrow senses for the studied fruit characters

\begin{tabular}{|c|c|c|c|c|c|c|c|c|c|}
\hline \multirow[t]{2}{*}{ GP } & \multicolumn{3}{|c|}{ N.L.F } & \multicolumn{3}{|c|}{ F.F } & \multicolumn{3}{|c|}{ P.T } \\
\hline & S1 & S2 & comb & S1 & S2 & comb & S1 & S2 & Comb \\
\hline$\sigma^{2} A$ & -0.573 & -0.989 & -0.61 & 3.583 & 2.467 & 0.659 & 0.631 & 0.153 & 0.421 \\
\hline$\sigma^{2} D$ & 1.134 & 1.759 & 2.812 & 3.426 & 1.378 & 0.911 & 2.828 & 0.784 & 2.365 \\
\hline$\sigma^{2} r$ & 1.833 & 1.648 & 3.567 & 3.154 & 3.941 & 2.95 & 1.136 & 0.889 & 1.593 \\
\hline$\sigma^{2} A \times S$ & & & -0.059 & & & 0.034 & & & -0.085 \\
\hline$\sigma^{2} D \times S$ & & & 0.080 & & & -0.063 & & & 1.248 \\
\hline$\sigma^{2} r \times S$ & & & -0.086 & & & 0.049 & & & 0.432 \\
\hline $\mathbf{h}^{2} \mathbf{b} \%$ & 72.1 & 88.11 & -92.38 & 94.42 & 93.62 & 97.02 & 96.76 & 91.51 & 68.78 \\
\hline$h^{2} n \%$ & -73.62 & -113 & -25.57 & 64.66 & 56.95 & 40.73 & 17.65 & 14.97 & 10.39 \\
\hline D.d & -1.979 & -1.778 & -4.609 & 0.678 & 0.802 & 1.175 & 2.117 & 2.261 & 2.37 \\
\hline
\end{tabular}

Table 6: Estimates of genetic parameters and heritability in broad and narrow senses for the studied chemical traits

\begin{tabular}{|c|c|c|c|c|c|c|c|c|c|}
\hline \multirow[t]{2}{*}{ GP } & \multicolumn{3}{|c|}{ T.S.S } & \multicolumn{3}{|c|}{ V.C } & \multicolumn{3}{|c|}{ Lyco. } \\
\hline & S1 & S2 & comb & S1 & S2 & comb & S1 & S2 & Comb \\
\hline$\sigma^{2} A$ & 79.5 & 25.37 & -0.099 & 0.02 & 0.01 & 0.00 & 0.00 & 0.00 & 39.51 \\
\hline$\sigma^{2} D$ & 88.43 & 43.94 & 0.748 & 0.02 & 0.01 & 0.009 & 0.03 & 0.024 & 128.8 \\
\hline$\sigma^{2} r$ & 143.38 & 98.04 & 0.444 & 0.1 & 0.09 & 0.003 & 0.02 & 0.016 & 238.8 \\
\hline$\sigma^{2} \mathrm{~A} \times \mathrm{S}$ & & & -0.075 & & & 0.00 & & & 5.574 \\
\hline$\sigma^{2} \mathrm{D} \times \mathrm{S}$ & & & 0.25 & & & 0.001 & & & 3.61 \\
\hline$\sigma^{2} r \times S$ & & & -0.032 & & & 0.00 & & & 2.61 \\
\hline $\mathbf{h}^{2} \mathbf{b} \%$ & 88.78 & 85.01 & 71.62 & 61.56 & 54.17 & 81.58 & 83.87 & 85.28 & 87.13 \\
\hline $\mathbf{h}^{2} \mathbf{n} \%$ & 42.59 & 31.11 & -10.94 & 32.31 & 25.00 & -1.316 & -3.23 & -1.23 & 20.46 \\
\hline D.d & 1.053 & 1.316 & $>1$ & 0.951 & 1.08 & $>1$ & $>1$ & $>1$ & $>1$ \\
\hline
\end{tabular}




\section{REFERENCES}

Adalid, A.R, Salvador; V. Mercedes, and N. Feranando (2012). Analysis of the genetic control of B-carotene and 1-ascorbic acid accumulation in an orange-brownish wild cherry tomato accession. Euphytica , 184(3): 251-255.

Ashrafuzzaman, M.; M.A. Haque; M. R. Ismail; M. T. Islam; S.M. Shahidullah (2010). Genotypic and seasonal variation in plant development and yield attributes in tomato (lycopersicum esculentum Mill.) cultivars. International Journal of Botany, 6(1): 314-316.

Cocherham, C.C (1963). Estimation of genetic variances. Statistical Genetics and Plant Breeding. NAS. NRC, 982, PP.53-68.

Dod. V.N; P.B. Kale R.V. Wankhada (1992). Genetic analysis of fruit yield of tomato. J. Hill. Res. 12(1): 31-33 (C.F. Plant Breed. Abstr., 64; 10672).

Dodhol, V.K.;U.K. Kohi and S. Mehta (1999). Genetic analysis of fruit firmness and related in tomato. J. Hill. Res., 12(1):31-33 (C.F Plant Breed. Abst. 7(1):809).

El-Nagashy, P.A.(2012). Breeding program for improving yield and its components traits of tomato ( $L$. esculentum,Mill). M.S. Thesis,Mansoura University.

Garg. N, D.; S. Cheema and Aj. S. Dhatt. (2008). Genetics of yield quality and shelf life characteristics in tomato under normal and late planting conditions. EUOHYTICA Vol 159, No 1-2,275288, Dol: 10.1007/s 10681-007-9486-3.

Griffing, B. (1956). Concept of general and specific combining ability diallel crossing system. Aust. J. Biol. Sci., 9:463.

Hannan, M.M.; M.B. Ahmed; M. B.Roy ;R.Haydar and M.A. Rahman (2007). Heterosis, combining ability and genetics for brix $\%$, daysto first fruit ripening and yield in tomato (Lycopersicon esculentum Mill). Middle east Journal of scientific Research 2(3-4):128-131.

Kansouh, A.M. and A.G. Zakher (2011). Gene action and combining ability in tomato (Lycopersicon esculentum Mill). by line $\mathrm{x}$ tester analysis. J. plant pro. Mansoura Univ., 2(2):213-227.

Kumar, R.; S. K.Norange ;N.K. Sing ; R. K. Singh and M.K. Sing (2013). Combining ability analysis for yield and its components in Tomato (Lycopersicon esculentum Mill). Journal of agricultural science $5(2):$ 213-218.

LiHui, X. (2006). Heterosis and inheritance of main quality characters of tomato M.Sc. Thesis, Yang Zhou Univ., China.

Matzinger, D.F. and O. Kempthorne (1956). The modified diallel table with partial in breeding and interactions with environment. Genetics, 4:822-833.

Salib, F.S. (1999). Genetical studies on some morphological and physiological charactersof tomato varieties (Lycopersicon esculentum Mill) Ph.D. Thesis, Ain Shams Univ., Egypt. 
Santosh , K . and M.K. Sharma (2011). Exploitation of heterosis for yield and its contributing traits in tomato (SolanumLycopersicum $L$ ) International journal of Farm Science, 1 (2):45-55.

Seema, M.; D. Kumar and K. Mishra (2005). Combining ability for yield and yield components in tomato (Lycopersicon esculentum Mill). Journal of Sciences. 11 (2):107-112.

Sekhar, I . ; B.G. Prakash ; P.M. Salimath ; 0 .Srivedi and A.A. Patil (2010). Implications of heterosis and Combining ability among productive single cross hybrids in tomato. Electronic journal of plant breeding, 1(14):706-711.

Singh, R.K. and B.D. Chaudhary (1985). Biometrical Method in Quantative genetic Analysis. Katyani Publisher, New Dehli, Revised Ed.

Singh, S. K.; R. K. Naresh; K. V. Singh; Bhatnagar and A. Kumar (2011). General combining ability analysis of yield and its contributing traits in tomato (Lycopersicon esculentum, Mill). Plant Archives, 11 (1): 201-204.

\footnotetext{
طبيعة الفعل الجيني لبعض الصفات الإقتصادية في بعض أصناف الطماطم

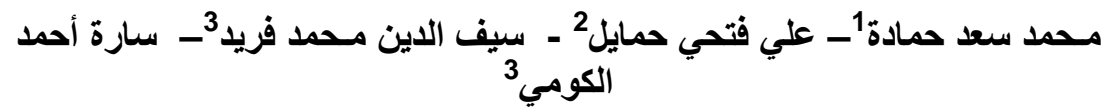

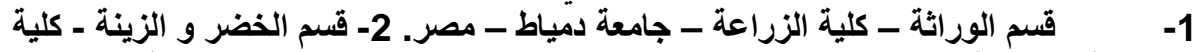
الزراعة - جامعة دمياط - مصر. 3- معهد بحوث البساتين - مركز البحوثة الزعة الزماعية ـ مصر.

تمت دراسة طبيعة الفعل الجيني لبعض الصفات الاقتصادية في بعض أصناف الطماطم و لهذا

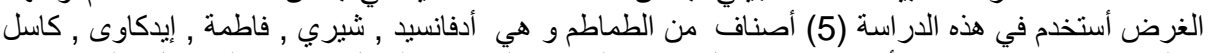

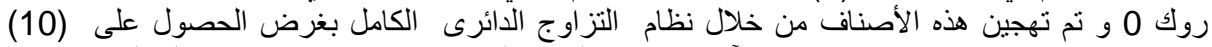

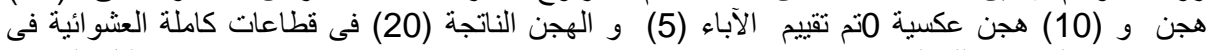

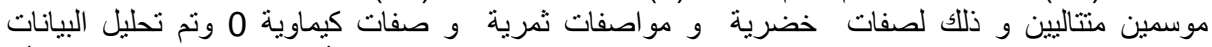

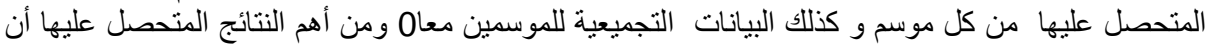

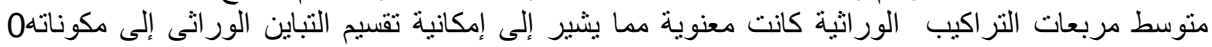

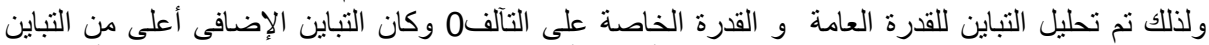

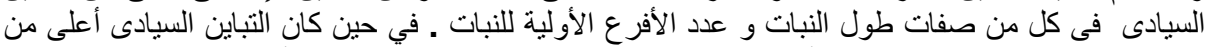

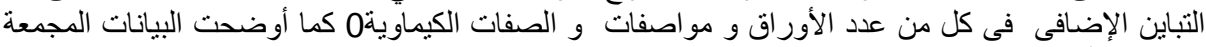
للموسمين أن درجة التوريث فى المدى الواسع كانت ل الضيق 26. 20.46\% بالنسبة لطول النبات ,عدد الأفرع الأولية لكل نبات ,المساحة الورقية , عدد الحجرات

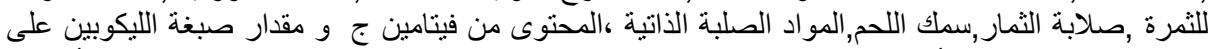

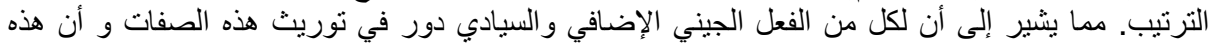

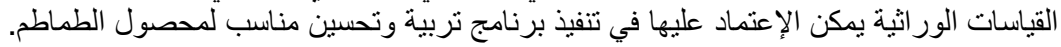

